\title{
ANALISIS SEMIOTIKA PADA COVER BUKU SERI PERCY JACKSON AND THE OLYMPIANS
}

\author{
Annisa Ayu Safitri ${ }^{1)}$, Shiti Gaziliai Achmad ${ }^{2)}$ \\ Program Studi Desain Komunikasi Visual, \\ Fakultas Bahasa dan Seni, Universitas Indraprasta PGRI \\ Jl. Nangka 58 C Tanjung Barat, Jakarta Selatan, 12530, Indonesia \\ annisaazyusafitri@gmail.com
}

\begin{abstract}
Abstrak
Karya sastra yang berkembang pesat saat ini adalah novel. Cover pada novel berperan penting dalam menarik perhatian calon pembaca. Ilustrasi cover pada novel harus dibuat semenarik mungkin karena pembaca cenderung beranggapan bahwa cover novel memiliki pesan yang akan mewakili isi novel. Cover novel yang akan diteliti adalah cover buku seri "Percy Jackson and The Olympians" karya Rick Riordan dengan genre fantasi. Buku seri ini terdiri dari 5 buah novel yang cover-nya dapat dikatakan berhasil mewakili isi dari masing-masing buku tersebut. Studi ini bertujuan untuk menganalisis cover buku seri "Percy Jackson and The Olympians" dengan menggunakan metode teori semiotika dari Charles Sanders Peirce untuk memaknai tanda-tanda visual yang ada pada cover buku. Hal ini dilakukan dengan mengkaji visualisasi, warna dan hubungan tanda dengan makna cover. Jadi, hasil penelitian adalah terbentuknya persepsi yang merupakan pesan pada cover buku seri "Percy Jackson and The Olympians" sehingga dapat mewakili isi buku tersebut.
\end{abstract}

Kata Kunci: Semiotika, Desain, Cover, Novel.

\begin{abstract}
Nowdays the novel books is a literary work that is rapidly developing. The cover of the novel had an important role to affects the interest of readers. Cover illustration in the novel must be made as best as possible because the readers will tent to assume that the novel cover has a message who will represents the content of the novel. The novel cover that will be research is about book cover of "Percy Jackson and The Olympians" who has a fantasy genre. This book consisted of five novel which is all covers can be successful in representing the contents of each novels. The purpose of this study is to anaylse all of the cover novel of "Percy Jackson and The Olympians" using Charles Sanders Peirce semiotics theory to analyse the meaning of visual sign in a novel cover. This research will be made by examining the visualization, colors, and relationship between sign and cover meaning on the cover novel. The result of this research is the formation of perception which is messages on the cover of the book series "Percy Jackson and The Olympians" so it can be represent the contents of the novel.
\end{abstract}

Keywords: Semiotics, Design, Cover, Novel.

Correspondence author: Annisa Ayu Safitri, annisaazyusafitri@gmail.com, Jakarta, and Indonesia 


\section{PENDAHULUAN}

Menurut Sumardjo dan Saini (1988: 3) dalam buku Pengantar Teori Sastra yang ditulis Siswanto, sastra adalah ungkapan pribadi manusia yang berupa pengalaman, pemikiran, perasaan, ide, semangat keyakinan dalam suatu bentuk gambaran konkret yang membangkitkan pesona dengan alat bahasa. Melalui karya sastra, seorang pengarang dapat menyampaikan pandangannya tentang kehidupan yang ada di sekitarnya. Karya sastra terdiri dari berbagai macam jenis. Di dalam karya sastra terdapat banyak genre yang menghasilkan keanekaragaman pada dunia sastra. Salah satu jenis karya sastra yang berkembang pesat saat ini adalah buku novel. Novel merupakan sebuah karya fiksi menawarkan dunia yang berisi model kehidupan yang diidealkan, dunia imajinatif yang dibangun melalui berbagai unsur intrinsiknya seperti peristiwa, plot, tokoh dan penokohan, latar, dan sudut pandang yang kesemuanya bersifat imajinatif, walaupun semua yang direalisasikan pengarang sengaja dianalogikan dengan dunia nyata tampak seperti sungguh ada dan benar terjadi, hal ini terlihat sistem koherasinya sendiri (Nurgiyantoro, 2010). Sebuah novel dapat diminati oleh pembaca jika memiliki alur cerita yang unik, juga penggunaan bahasa dan konflik yang menarik. Novel juga dapat terdiri dari beberapa buku, tidak hanya satu buku saja. Hal seperti ini biasa disebut dengan buku berseri. Semiotika berasal dari kata semeion, bahasa asal Yunani yang mempunyai arti tanda. Pada buku berseri biasanya terdapat beberapa tanda yang konsisten ada di setiap bukunya dan mempunyai maksud tertentu. Buku berseri memiliki keunikan daripada novel lainnya karena memiliki cerita yang berkelanjutan.

Buku seri "Percy Jackson and The Olympians" karya Rick Riordan adalah salah satu buku seri fantasi yang sudah memenangkan banyak awards. Buku seri ini bercerita tentang petualangan anak setengah dewa bernama Percy Jackson bersama dewa-dewi Olympia. Buku ini mengajarkan sejarah tentang mitologi Yunani dengan wujud cerita fantasi. Buku seri ini berjenis novel pentalogi, yaitu terdiri dari 5 buah novel dimulai dengan novel pertamanya yang terbit pada tahun 2005 dengan judul "Lightning Thief" (Riordan, 2017d) yang bahkan telah difilmkan dan novel terakhirnya yang terbit tahun 2009 dengan judul "The Last Olympian" (Riordan, 2017c). Selain itu, buku ini juga sudah diterjemahkan oleh banyak penerbit di berbagai negara, salah satunya di Indonesia oleh penerbit Mizan Fantasi.

Selain faktor cerita yang dapat menarik minat pembaca, hal yang penting dalam perancangan sebuah buku ada pada cover buku. Cover buku adalah pemandangan pertama yang akan dilihat oleh pembaca. Oleh sebab itu, cover pada buku akan mempengaruhi minat pembaca dan yang menjadi penentu sukses tidaknya sebuah buku dalam dunia sastra. Selain itu, cover juga digunakan sebagai salah satu media penyampaian pesan yang ada pada buku. Jika melibatkan ilmu Desain Komunikasi Visual (DKV) dalam perancangan cover buku akan membuat buku menjadi semakin menarik. Desain seperti ilustrasi atau tanda-tanda visual yang ada pada cover sebuah buku dapat menimbulkan pesan atau makna tertentu. Pesan yang disampaikan dapat membangun sebuah persepsi visual. Persepsi visual dalam psikologi persepsi adalah sebagai kemampuan untuk menterjemahkan apa yang dilihat oleh mata, yaitu jatuhnya cahaya masuk ke retina mata, sebagai hasil penglihatan (eyesight), akan tetapi penerjemahannya tidak sebatas pandangan mata melainkan juga melibatkan pikiran dan jiwa (Iskandar, 2011).

Pada perancangan cover buku, desain harus disesuaikan dengan isi buku. Hal ini menjadi penanda bahwa sebuah desain pada cover buku memiliki makna yang berhubungan erat dengan isi buku tersebut. Makna atau pesan yang terdapat pada cover buku dapat dijelaskan melalui tanda-tanda visual yang muncul. Cover buku seri "Percy Jackson and The Olympians" karya Rick Riordan terbitan tahun 2014 diperbaharui sebagai peringatan $8^{\text {th }}$ anniversary Percy Jackson dengan ilustrasi cover yang dibuat oleh John Rocco (Riordan, 2017b). Di Indonesia, cover ini diterbitkan oleh penerbit Mizan Fantasi. Cover ini diperbaharui di seluruh dunia, tidak hanya di Indonesia saja. Terbitan cover buku ini memiliki keunikan dari cover buku yang telah ada sebelumnya. Hal ini karena jika kelima bukunya dijejerkan, covernya akan menampilkan gambar yang saling berhubungan baik dilihat dari depan ataupun jika ditumpuk dan dilihat dari samping.

Studi ini bertujuan untuik menganalisis kelima cover buku seri "Percy Jackson and The Olympians" karya Rick Riordan. Hal ini dilakukan dengan mengkaji elemen bentuk dan warna serta persepsi yang terbentuk pada kelima cover buku tersebut. Penelitian ini dikaji dengan 
menggunakan teori semiotika Charles Sanders Pierce pada Desain Komunikasi Visual. Teori Semiotika digunakan untuk menganalisis makna visual dan tanda-tanda visual yang muncul pada cover buku seri tersebut.

\section{METODE PENELITIAN}

Penulisan ini menggunakan pendekatan metode penelitian kualitatif. Menurut Imam Gunawan, dalam artikel yang berjudul "Metode Penelitian Kualitatif", yaitu metode kualitatif berusaha memahami dan menafsirkan makna suatu pristiwa interaksi tingkah laku manusia dalam situasi tertentu menurut perspektif peniliti sendiri, penelitian yang menggunakan penelitian kualitatif bertujuan untuk memahami obyek yang diteliti secara mendalam, metode ini bertujuan untuk mengembangkan konsep, sensitivitas, pada masalah yang dihadapi, menerangkan realitas yang berkaitan dengan penelusuran teori dari bawah (grounded theory) dan mengembangkan pemahaman satu atau lebih dari fenomena yang dihadapi (Gunawan, 2013). Penelitian ini akan menggunakan metode kualitatif tersebut, bahwa penelitian mengenai cover buku seri "Percy Jackson and The Olympians" karya Rick Riordan ini diteliti secara alamiah tidak melakukan eksperimen secara langsung, yaitu dengan menganalisis berdasarkan pemikiran peneliti. Metode yang digunakan adalah analisis deskriptif dengan pengumpulan data dari literatur yang terdapat pada google cendikia dan pemberitaan di internet.

Cover buku adalah pemandangan pertama yang akan dilihat oleh pembaca. Oleh sebab itu, cover pada buku menjadi hal yang penting dalam perancangan sebuah buku. Jika menggunakan ilmu Desain Komunikasi Visual (DKV) dalam perancangan sebuah cover buku dapat membuat buku menjadi semakin menarik. Di dalam cover buku terdapat tanda-tanda visual berupa elemen desain. Elemen desain merupakan hal yang terpenting dalam sebuah desain karena hal ini yang akan memunculkan prinsip desain. Penulisan artikel ini akan mengkaji elemen bentuk, warna dan persepsi visual yang terbentuk dari cover buku seri "Percy Jackson and The Olympians". Elemen bentuk adalah seperangkat garis yang ditempatkan berdekatan memiliki diameter, tinggi, dan lebar serta sebagai objek dua dimensi (Putri, 2013). Sedangkan warna adalah media paling akhir dalam komunikasi simbolik dan yang terpenting karena dengan warna seorang desainer dapat mempilkan identitas, menyampaikan pesan atau menarik perhatian serta menegaskan sesuatu (Putri, 2013). Analisis teori semiotika yang dipakai adalah Charles Sanders Pierce yang dikenal dengan segitiga makna yang didalamnya terdapat representamen, objek, dan interpretan. Tanda-tanda tersebut digolongkan menjadi ikon, indeks dan simbol (Peirce, 1982).

\section{HASIL DAN PEMBAHASAN}

Buku seri "Percy Jackson and The Olympians" karya Rick Riordan adalah salah satu buku seri fantasi yang sudah memenangkan banyak awards. Buku seri ini bercerita tentang petualangan anak setengah dewa bernama Percy Jackson bersama dewa-dewi Olympia. Buku ini mengajarkan sejarah tentang mitologi Yunani dengan wujud cerita fantasi. Buku seri ini berjenis novel pentalogi, yaitu terdiri dari 5 buah novel dimulai dengan novel pertamanya yang terbit pada tahun 2005 dengan judul "Lightning Thief" (Riordan, 2017d) yang bahkan telah difilmkan dan novel terakhirnya yang terbit tahun 2009 dengan judul "The Last Olympian" (Riordan, 2017c). Selain itu, buku ini juga sudah diterjemahkan oleh banyak penerbit di berbagai negara, salah satunya di Indonesia oleh penerbit Mizan Fantasi.

Cover buku seri "Percy Jackson and The Olympians" karya Rick Riordan terbitan tahun 2014 yang diperbaharui sebagai peringatan $8^{\text {th }}$ anniversary Percy Jackson dengan ilustrasi cover yang dibuat oleh John Rocco (Riordan, 2017b). Di Indonesia, cover ini diterbitkan oleh penerbit Mizan Fantasi. Cover ini diperbaharui di seluruh dunia, tidak hanya di Indonesia saja. 


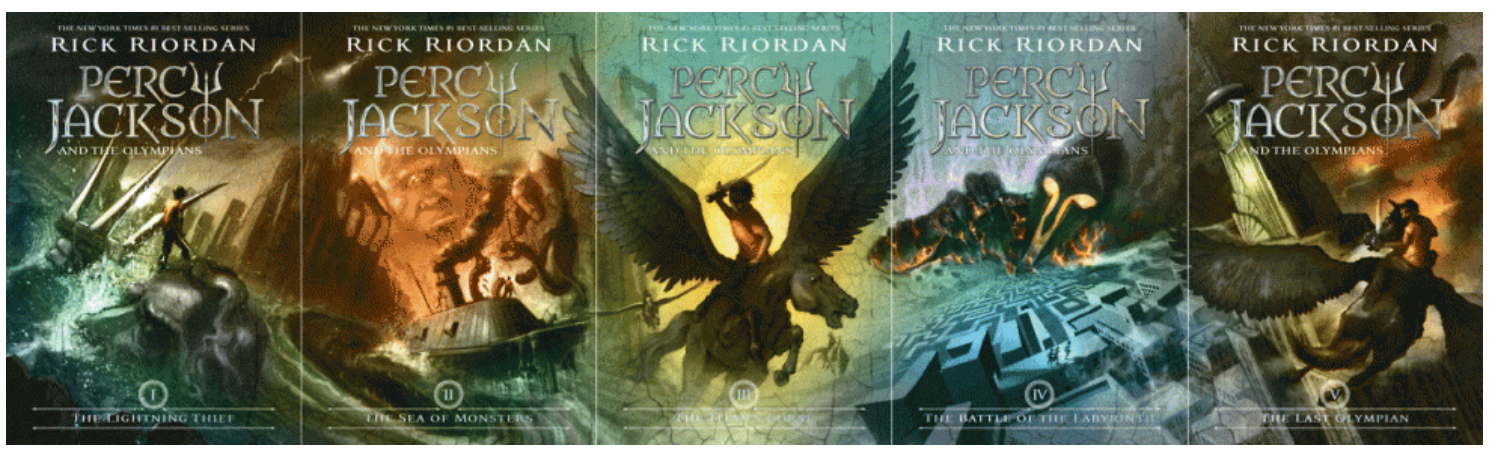

Gambar 1 Cover Buku Seri Percy Jackson and The Olympians Dilihat Tampak Depan

Alur keterbacaan dari setiap cover novel pada buku seri ini adalah sama yaitu dari atas lalu ke bawah. Bagian paling atas cover terdapat penulisan awards buku ditampilkan untuk menarik minat pembaca, porsi tulisan dibuat kecil karena bukan termasuk headline. Kemudian di bawahnya terdapat nama penulis menggunakan huruf serif. Tulisan ini menggunakan jarak spasi antar huuruf yang cukup besar agar tulisan memiliki keterbacaan yang jelas ketika dilihat dari dekat ataupun dari jauh. Selanjutnya tulisan yang menjadi headline yaitu judul buku seri menggunakan huruf serif dekoratif. Font jenis ini memiliki kaki dan termasuk dekoratif karena adanya gambaran trisula atas gabungan huruf "y" pada kata "Percy" dan huruf "o" pada kata "Jackson". Penempatan judul buku seri ini mengambil dominasi dari keselurahan cover. Terdapat penekanan pada judul buku seri yang diberi ukuran lebih besar dibanding dengan teks atau tulisan yang lainnya. Lalu terdapat ilustrasi pada cover. Kemudian bagian bawah cover terdapat penomoran buku yang ditulis menggunakan huruf romawi dan ditambah adanya lingkaran yang mengelilingi romawinya. Selajutnya yaitu judul novel menggunakan huruf serif. Judul novel dibuat lebih kecil di paling bawah. Penempatan ini bertujuan agar orang melihat ilustrasinya dulu baru judulnya dikarenakan alur bacanya adalah dari atas ke bawah. Tulisan yang ada pada cover menggunakan huruf kapital semua.

Cover ini menunjukkan perjalanan petualangan Percy Jackson sebagai anak demigod (anak setengah dewa) bersama dengan dewa-dewi Olympia karena adanya ramalan besar yang merujuk pada Percy. Kronos dan bangsa titan ingin mengambil alih kekuasaan dewa-dewi Olympia sehingga fokus pada novel ini adalah perjuangan Percy untuk mencegah bangkitnnya Kronos dan bangsa Titan dari kutukannya. Terbitan cover buku ini memiliki keunikan daripada cover buku yang telah ada sebelumnya. Hal ini dapat dilihat jika kelima bukunya dijejerkan, cover-nya akan menampilkan gambar yang saling berhubungan baik dilihat tampak depan ataupun jika ditumpukan dan dilihat tampak samping.

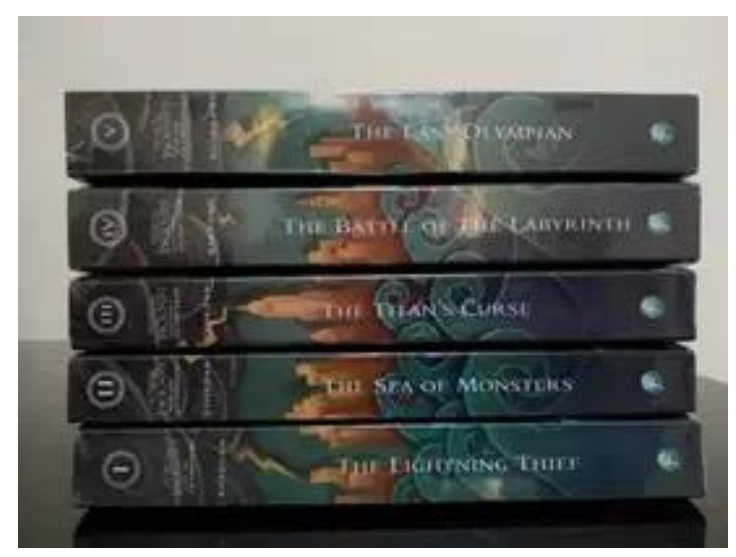

Gambar 2 Cover Buku Seri Percy Jackson and The Olympians Dilihat Tampak Samping 
Desain yang di-layout saat buku ditumpuk dan dilihat dari samping terlihat menyatu karena terdapat prinsip desain keseimbangan dan kesatuan pada cover ini. Alur keterbacaan cover ini jika dilihat tampak samping masih sama seperti saat cover dilihat tampak depan yaitu dari atas ke bawah. Bagian paling atas terdapat penomoran buku lalu dilanjut dengan judul buku seri dan nama penulis. Tulisan judul buku seri dan nama penulis ini terlihat lebih kecil daripada judul. Kemudian terdapat bagian yang menjadi point of interest yaitu judul novel. Di bagian paling bawah ditempatkan logo penerbit Mizan Fantasi. Ilustrasi yang dibuat adalah elemen dengan bentuk bergelombang penanda ombak dan background perkotaan serta terdapat petir di beberapa tempat menandakan badai. Ombak dan badai tersebut pertanda melambangkan efek dramatis dari adanya pertempuran yang selalu ada pada cerita setiap novel.

\section{Cover Percy Jackson and The Olympians: The Lightning Thief}

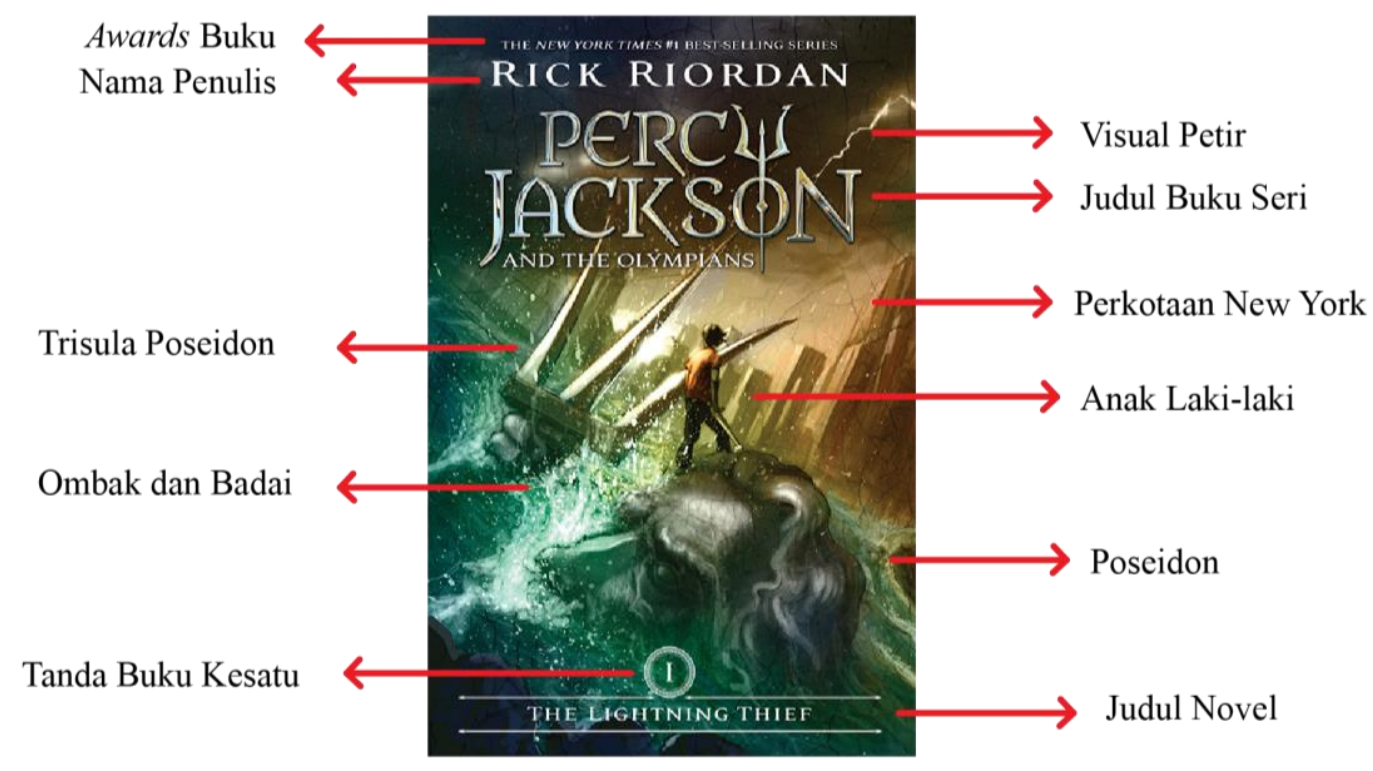

Gambar 3 Cover novel The Lightning Thief

\section{Visualisasi cover novel}

Novel Percy Jackson and The Olympians: The Lightning Thief merupakan novel pertama dari buku seri ini. Pada cover ini terdapat ilustrasi visual petir yang menandakan isi novel ini ada hubungannya dengan petir. Lalu terdapat visual anak laki-laki yang menjadi tokoh utama dalam cerita pada novel. Terdapat penekanan juga pada ilustrasi seorang dewa yaitu Poseidon dan trisulanya sebagai simbol. Trisula tersebut sedang dipegang oleh sang dewa dan memiliki ukuran ilustrasi yang besar sehingga ilustrasi ini menjadi point of interest dari cover novel ini. Kemudian terdapat gambaran perkotaan New York sebagai background cover novel tersebut. Selain itu, terdapat ilustrasi ombak dan badai juga menjadi background.

Penggunaan warna adalah dominasi warna biru laut dan warna coklat untuk perkotaan. Warna biru dalam psikologi warna memiliki makna kebenaran dan kebijaksanaan. Jika dipadukan dengan warna hangat, warna ini juga bisa bermakna semangat. Prinsip desain pada cover novel adalah kesatuan dan keseimbangan. Keseimbangan yang diterapkan adalah simetris. Hal ini dapat dilihat dari peletakan objek yang beraturan yaitu teks dengan ilustrasi gambar memiliki sisi yang teratur.

\section{Hubungan tanda dengan makna cover}

Tanda pertama merujuk pada Poseidon dan Trisula Poseidon yang berada dalam lautan dapat dimaknai bahwa ilustrasi ini menggambarkan simbol Poseidon. Tanda kedua terdapat visual 
anak laki-laki yang menjadi tokoh utama di novel yaitu Percy Jackson yang sedang memegang pedangnya yaitu Riptide. Hal ini berkaitan dengan tanda pertama sebagai pertanda bahwa Percy adalah anak setengah dewa yaitu Poseidon yang dapat mengendalikan air. Tanda ketiga adalah background ombak dan badai menjadi tanda kekuasaan Poseidon di lautan. Tanda keempat adalah petir sebagai pertanda kemurkaan Zeus karena hilangnya pedang petir Zeus di cerita novel ini. Tanda kelima adalah judul novel "The Lightning Thief" yang berarti pencuri petir. Novel ini menceritakan jati diri Percy sebagai demigod dari anak Poseidon. Percy juga anak yang menjadi tersangka pencurian pedang petir Zeus dan akhirnya mendapatkan misi untuk menemukan petir Zeus.

\section{Cover Percy Jackson and The Olympians: The Sea of Monsters}

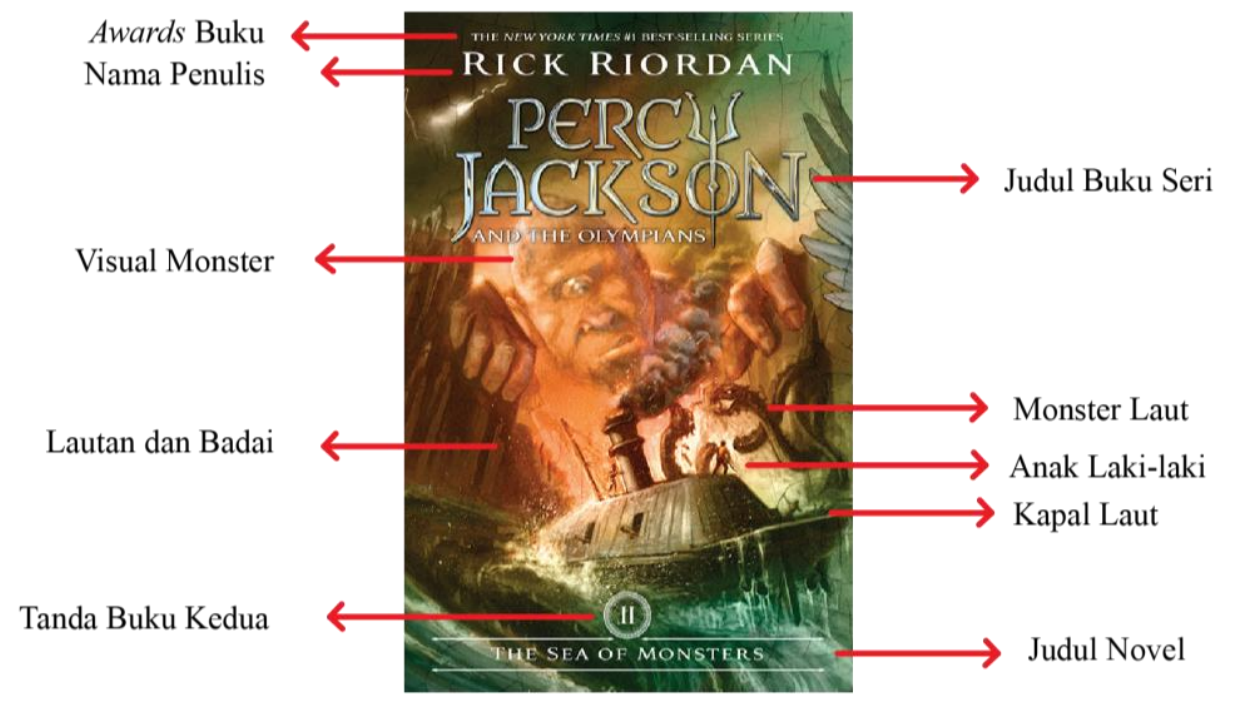

\section{Visualisasi cover novel}

Gambar 4 Cover novel The Sea of Monsters

Novel Percy Jackson and The Olympians: The Sea of Monsters merupakan novel kedua dari seri ini. Konsep pada cover buku ini terdapat ilustrasi yang menjadi point of interest yaitu ilustrasi monster Cyclops yang menjadi penekanan pada desain cover. Jadi, pembaca yang melihat cover ini langsung fokus pada monster Cyclops tersebut. Selain itu, terdapat juga ilustrasi anak laki-laki dan visual kapal laut di lautan. Lalu ada visual monster laut juga dengan dilengkapi background badai sebagai pendukung.

Penggunaan warna pada cover novel didominasi oleh warna merah kejinggaan gelap dan dipadukan dengan sedikit warna hijau. Warna jingga dalam teori warna yaitu untuk meningkatkan rangsangan dan daya tarik. Adanya warna sedikit kelam pada cover untuk menunjukkan kengerian akan monster yang ada pada cerita novel ini. Prinsip desain pada cover novel adalah keseimbangan simetris dan menampilkan kesatuan yang ada pada ilustrasi walaupun dengan penggambaran ilustrasi monster yang lebih besar dari kapal laut.

\section{Hubungan tanda dengan makna cover}

Tanda pertama merujuk pada visual anak laki-laki yang berperan sebagai tokoh utama di novel yaitu Percy. Tanda kedua sebagai point of interest yaitu visual monster Cyclops bernama Polyphemus. Hal ini pertanda pada novel menceritakan petualangan Percy dan teman-temannya yang harus berhadapan dengan Polyphemus. Tanda ketiga adalah visual monster laut Charybdis dan Skylla yang menjadi tanda bahwa Percy sedang berada di lautan yang dipenuhi para monster, tempat yang mengerikan. Tanda keempat, background lautan dan badai juga menjadi latar tempat dan nuansa yang harus dihadapi Percy di lautan penuh monster. Tanda kelima adalah judul "The Sea of Monster" yang berarti lautan monster. Novel ini menceritakan petualangan perjuangan 
Percy dan teman-temannya untuk mendapatkan bulu domba emas yang Polyphemus miliki untuk menyelamatkan perkemahan demigod yang terancam bahaya akibat pohon Thalia yang menjadi pelindung perkemahan telah diracuni. Satu-satunya cara menyembuhkan pohon Thalia adalah dengan bulu domba emas.

\section{Cover Percy Jackson and The Olympians: The Titan's Curse}

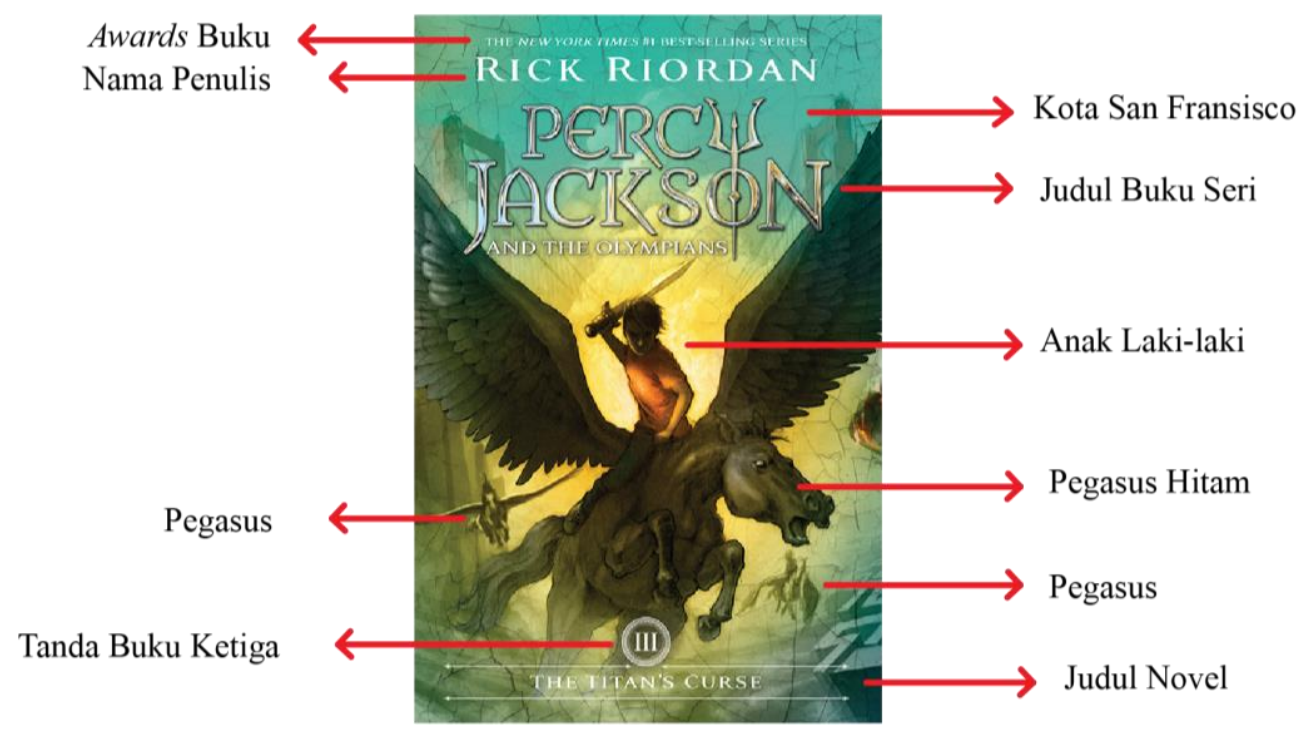

Gambar 5 Cover novel The Titan's Curse

\section{Visualisasi cover novel}

Novel Percy Jackson and The Olympians: The Titan's Curse merupakan novel ketiga dari seri ini. Ilustrasi anak laki-laki yang sedang menunggangi pegasus hitam menjadi point of interest cover ini. Visual anak laki-laki ini memiliki makna bahwa pusat cerita ada pada perjalanan petualangan anak ini. Ekspresinya serius dan penggambaran dia yang sedang mengangkat pedang pertanda ia akan pergi bertempur. Visual pegasus hitam yang ditumpangi anak laki-laki dalam cover ini adalah pegasus hitam bernama "Blackjack". Ilustrasi ini sebagai visual utama atau dominasi cover. Hal ini disebabkan adanya andil dari pegasus dari perjalanan petualangan anak tersebut. Sedangkan pada background terdapat sekelompok pegasus lainnya yang menjadi tumpangan kendaraan untuk teman-teman tokoh utama novel ini. Selain itu, ada background kota San Fransisco. Hal ini pertanda petualangan yang berada di daerah San Fransisco. Tempat tersebut memiliki peranan penting pada novel. Ilustrasi kota dibuat opacity sehingga terlihat seperti transparan.

Pada cover ketiga ini dibuat gelap untuk objek utama visual ilustrasinya dan menggunakan background yang terang. Hal ini menimbulkan kesan yang memukau dan meyilaukan ketika melihat cover ini. Dominasi warna yang dipakai untuk background adalah warna hijau dan kuning. Warna kuning dijadikan sebagai penunjang visual point of interest untuk menarik perhatian. Dalam teori warna, warna kuning disebutkan dapat merangsang aktivitas mental dan membangkitkan energi. Sedangkan warna hijau merupakan warna alam dan dimaknai dengan harapan. Penggunaan warna kuning dan hijau pada background dengan warna objek yang gelap menimbulkan prinsip desain yang seimbang pada cover.

\section{Hubungan tanda dengan makna cover}

Tanda pertama merujuk pada dominasi ilustrasi yang ditampilkan adalah anak laki-laki yang sedang menunggangi pegasus hitam dengan pedang terayun. Hal ini dapat dimaknai dengan isi novel yang menceritakan petualangan Percy dengan pegasus yang ia selamati bernama 
Blackjack dalam misi penyelamatan dewi Artemis. Tanda kedua ada pada background San Fransisco, pertanda bahwa pertempuran terjadi di sekitar daerah tersebut, lebih tepatnya di Gunung Tamalpais. Tanda ketiga yaitu judul dari novel yaitu "The Titan's Curse" yang berarti kutukan bangsa titan. Pada novel menceritakan ramalan besar yang menyangkut tentang anak dari salah satu dewa besar (Zeus, Poseidon dan Hades) yang akan menyelamatkan Olympus atau menghancurkannya. Lalu yang terlihat harus menanggung ramalan itu adalah Percy. Pada novel juga difokuskan pada cerita tentang kutukan yang didapati Kronos dan bangsa titan.

\section{Cover Percy Jackson and The Olympians: The Battle of The Labyrinth}

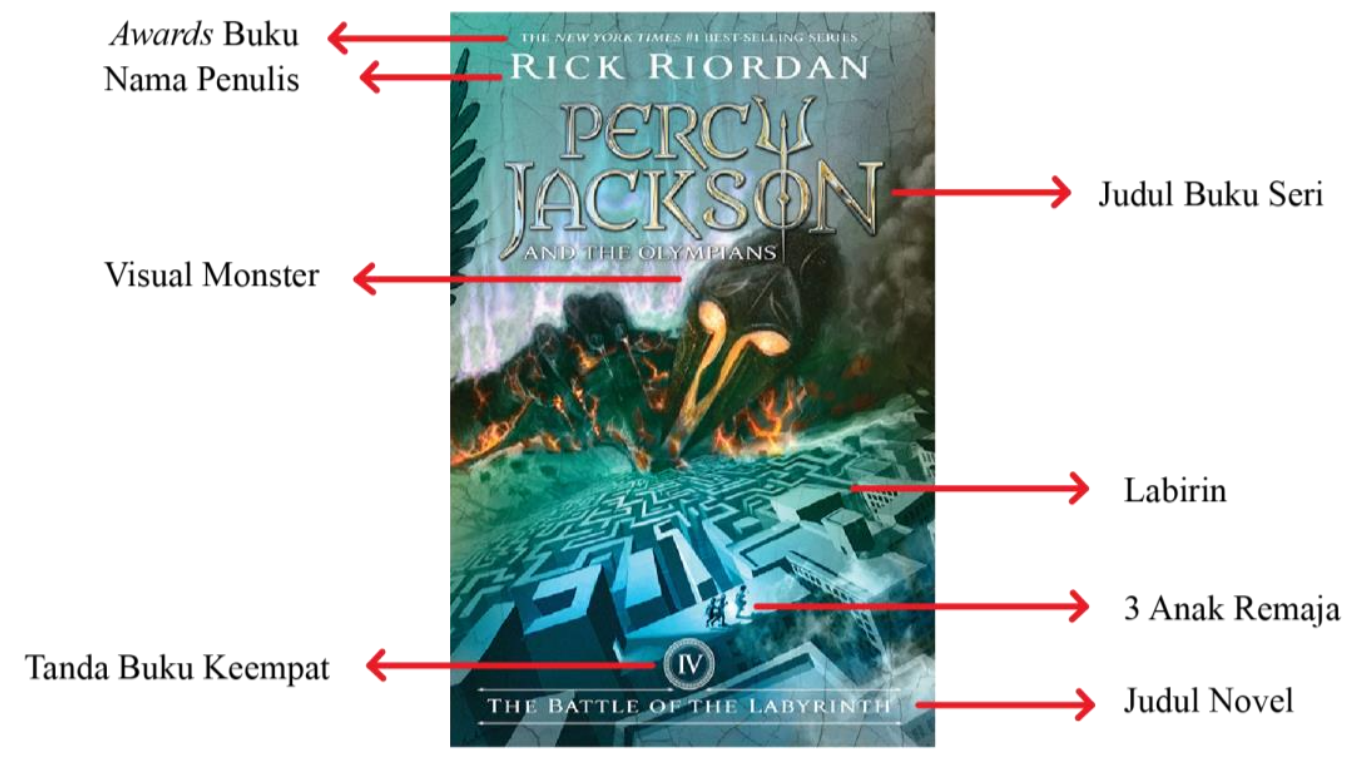

Gambar 6 Cover novel The Battle of The Labyrinth

\section{Visualisasi cover novel}

Novel Percy Jackson and The Olympians: The Battle of The Labyrinth merupakan novel keempat dari seri ini. Ilustrasi monster yang ada di labirin menjadi point of interest pada cover ini. Visual monster yang digambarkan adalah sosok "Kronos" yang digambarkan menakutkan dan sangat kuat. Selain itu, ada visual labirin berliku-liku sebagai background pertanda bahwa labirin memegang peranan penting dalam isi cerita. Lalu ada visual anak-anak yang digambarkan kecil yang sedang kabur dari kejaran monster. Ilustrasi visual monster dibuat sangat besar jika dibandingkan visual anak-anak yang sangat kecil pada cover. Hal ini pertanda fokus cerita novel ada pada monsternya.

Pada cover novel, warna didominasi oleh nuansa biru dan monster yang diberi warna gelap hitam. Biru dalam psikologi warna melambangkan pengaruh yang besar dan semangat jika dipadukan dengan warna lain. Penggunaan warna biru pada cover untuk menimbulkan kesan keseriusan dan kekuatan. Lalu warna hitam abu-abu pada visual monster memiliki makna negatif kelam kejahatan. Warna ini juga dipadukan dengan merah memiliki makna kekuatan dan menimbulkan kesan menakutkan. Ilustrasi dibuat seimbang simetris, perpaduan teks dan ilustrasi terlihat menampilkan prinsip desain kesatuan dan keseimbangan.

\section{Hubungan tanda dengan makna cover}

Tanda pertama merujuk pada monster Kronos yang mengejar anak-anak yaitu Percy, Annabeth dan Grover di labirin. Hal ini memberikan pertanda bahwa Kronos adalah monster yang sangat kuat dan ditakuti. Hubungannya dengan isi cerita novel adalah kebangkitan Kronos sebagai monster jahat dalam mitologi yunani dan ingin menguasai Olympus dan mengambil alih kekuasaan dewa-dewi Olympia. Kebangkitan Kronos membawa pertanda akan adanya 
pertempuran dahsyat antara dewa-dewi Olympia dan para demigod dengan pasukan Kronos. Tanda kedua adalah judul novel "The Battle of The Labyrinth" yang berarti pertempuran labirin. Selain itu, adanya dukungan visual labirin pada cover mengartikan labirin memegang peranan penting. Pada cerita novel ini, akan ada pertempuran antara pasukan Kronos yang berhasil menemukan kunci labirin (yang disebut sebagai benang merah Ariadne) yang dapat menghubungkan salah satunya ke perkemahan demigod dan menyerang perkemahan tersebut. Novel ini merupakan lanjutan kisah Percy Jackson dan teman-teman dengan misi menemukan Deadalus sebagai pencipta labirin tersebut untuk mempertahankan perkemahan demigod.

\section{Cover Percy Jackson and The Olympians: The Last Olympian}

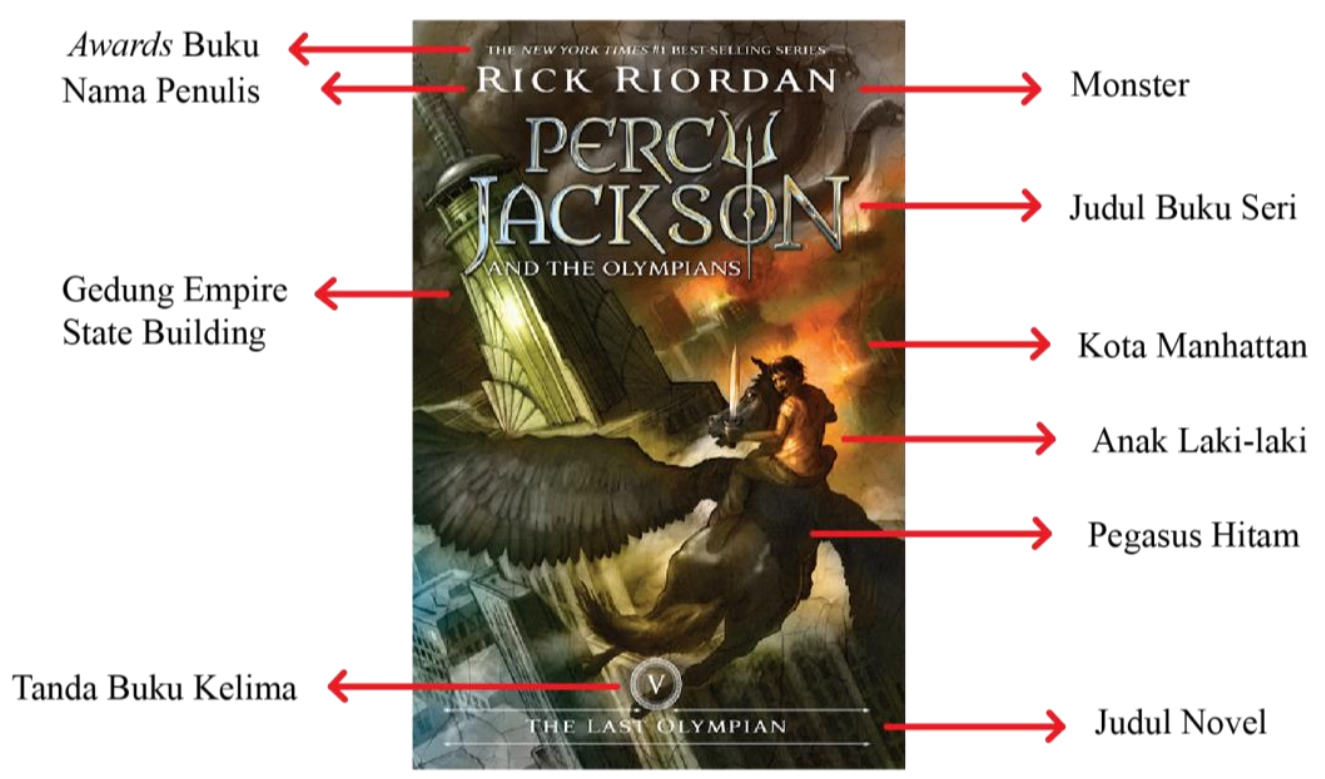

Gambar 7 Cover novel The Last Olympian

\section{Visualisasi cover novel}

Novel Percy Jackson and The Olympians: The Last Olympian merupakan novel kelima dan sekaligus sebagai novel terakhir dari seri ini. Ilustrasi yang ditampilkan sebagai dominasi cover adalah seorang anak laki-laki yang sedang menunggangi pegasus hitam. Ilustrasi visual utama ini sebelumnya sudah dipakai di buku ketiga, namun dipakai kembali dengan penggambaran sisi yang berbeda dan background yang berbeda. Sehingga akan menampilkan persepsi yang berbeda juga. Selain itu, terdapat visual gedung Empire State Building yang terlihat sebagai visual utama juga. Kemudian ada background kota Manhattan di New York yang sedang kacau pertanda pertempuran sedang terjadi. Lalu ada visual monster yang berada di antara kabut kekacauaan kota.

Pada cover terkahir ini, warna yang didominasi adalah warna gelap hitam ke abu-abuan. Hal ini menggambarkan kekacauaan dan kekelaman. Visual gedung Empire State Building yang diberi warna kuning keemasan sebagai point of interest yang muncul karena di sekitarnya merupakan warna yang gelap. Lalu ada sedikit warna merah kejinggaan pada background kota dan baju yang dipakai anak laki-laki pada cover yang memiliki makna semangat dan keberanian. Layout yang terbentuk terlihat seimbang walaupun dengan ilustrasi yang ditampilkan dibuat miring. Pada cover ini tetap menjaga keseimbangan dan kesatuan sama seperti cover lainnya pada buku seri ini. 


\section{Hubungan tanda dengan makna cover}

Tanda pertama merujuk pada visualisasi anak laki-laki yang tak lain adalah Percy yang sedang menunggangi pegasus hitam BlackJack. Hal ini pertanda pertempuran dahsyat yang diceritakan pada novel dipimpin oleh Percy. Visual Percy diperlihatkan bersemangat dan penuh keberanian sambil memegang pedangnya yaitu Riptide. Tanda kedua adalah background perkotaan Manhattan yang kacau dan hancur pertanda bahwa tempat pertempuran antara kubu Percy dengan kubu Kronos adalah di Manhattan. Lalu tanda ketiga adalah visual gedung pertanda tujuan yang dituju Kronos adalah gedung Empire State Building. Gedung tersebut merupakan tempat takhta dari dewa-dewi Olympia. Lalu tanda keempat adalah visual monster yang terlihat diantara kabut kekacauan kota adalah Typhon, yaitu monster terkuat dari kubu Kronos. Monster ini berwujud badai. Hal ini pertanda pada novel menceritakan perang antara Zeus dan dewa lainnya dengan Typhon, sehingga Percy beserta teman-temannya harus menghadapi Kronos untuk mempertahakan Olympus. Tanda terakhir adalah judul novel yaitu "The Last Olympian" yang berarti dewi Olympia terakhir. Dewi Olympia yang dimaksud adalah Dewi Hestia sebagai dewi satu-satunya yang berada di Olympus ketika perang dengan Kronos sedang berlangsung.

\section{SIMPULAN}

Sebuah novel memiliki cover dengan desain yang menarik untuk mempengaruhi pembaca. Desain dari cover sendiri memiliki hubungan tanda dan makna dengan isi dari novel. Pada buku seri Percy Jackson and The Olympians karya Rick Riordan memiliki cover yang mewakili dari isi novel. Alur keterbacaan dari cover buku seri ini semuanya sama yaitu dari atas lalu ke bawah. Jenis font yang digunakan pada setiap tulisan di cover adalah jenis font serif. Desain yang di-layout pada novel pertama hingga terakhir jika dijejerkan dan dilihat tampak depan terlihat menyatu. Begitu pula jika ditumpuk dan dilihat tampak samping terlihat menyatu. Hal ini disebabkan karena desain cover menggunakan prinsip desain kesatuan dan keseimbangan.

Point of interest dari cover buku pertama adalah visual ilustrasi Poseidon dengan simbol trisulanya. Hal ini pertanda terungkapnya Percy Jackson sebagai anak dari Poseidon. Pada cover buku kedua, visual monster Polyphemus sebagai pertanda pada novel menceritakan petualangan Percy dan teman-temannya dalam upaya penyelamatan pohon Thalia harus berhadapan dengan Polyphemus. Cover buku ketiga menampilkan ilustrasi anak laki-laki yang sedang menunggangi Pegasus hitam. Pada cover ini dibuat dengan objek berwarna gelap dan background yang terang untuk dapat menarik kesan memukau dan menarik minat pembaca. Cover ini pertanda isi novel menceritakan petualangan Percy menyelamatkan pegasus hitam yang dinamai Blackjack dalam misi penyelamatan dewi Artemis. Kemudian cover novel keempat terdapat ilustrasi Percy dan teman-temannya yang sedang dikejar monster menakutkan dalam labirin. Hal ini pertanda isi novel menceritakan kebangkitan Kronos dan pertempuran antara Percy dengan para monster yang keluar dari labirin untuk menyelamatkan perkemahan demigod. Paca cover novel terakhir, terdapat visual ilustrasi Percy yang sedang menunggangi pegasus hitam yang sudah ada pada cover novel ketiga. Tetapi, cover ini menampilkan persepsi yang berbeda. Background cover menggambarkan perkotaan Manhattan dalam kekacauan dan kehancuran serta terdapat visual gedung Empire State Building sebagai point of interest. Hal ini sebagai tanda adanya pertempuran besar di Manhattan antara kubu Percy dan kubu Kronos yang ingin mengambil alih kekuasaan dewa-dewi Olympia. Gedung State Building sebagai simbol Olympus, tempat bertakhta dewadewi Olympia.

\section{DAFTAR PUSTAKA}

Gunawan, I. (2013). Metode penelitian kualitatif. Jakarta: Bumi Aksara.

Iskandar, M. S. (2011). Pembentukan persepsi visual pada iklan televisi. Jurnal Visualita DKV, $3(1), 1-21$.

Nurgiyantoro, B. (2010). Teori pengkajian fiksi. Yogjakarta: Gadjah Mada University Press. 
Jackson, P. (2014). The lightning thief (Cover 8 Th anniversary Percy Jackson).. Retrieved From Mizanstore.Com Website: Https://Mizanstore.Com/Percy_Jackson_:_The_Lightning Thief_(Cover_8_Th_Anniversary_Perc_56171\#Tab-3.

Peirce, C. S. (1982). Logic as semiotics: The theory of sign. Bloomington: Indiana Universty Press.

Putri, D. (2013). Memahami elemen-elemen dalam desain. Retrieved from https://ideducation.com/articles/memahami-elemen-elemen-dalam-desain/

Riordan, R. (2017a). Percy Jackson and the olympians. Retrieved from readriordan.com website: https://www.readriordan.com/series/percy-jackson-and-the-olympians/

Riordan, R. (2017b). Percy Jackson and the olympians boxed set. Retrieved from readriordan.com website: https://www.readriordan.com/book/percy-jackson-and-the-olympians-boxed-set/

Riordan, R. (2017c). The last olympian. Retrieved from readriordan.com website: https://www.readriordan.com/book/the-last-olympian/.

Riordan, R. (2017d). The lightning thief. Retrieved from readriordan.com website: https://www.readriordan.com/book/the-lightning-thief/.

Siswanto, W. (2008). Pengantar teori sastra. Grasindo.

Sumardjo., \& Saini, K. M. (1988). Apresiasi kesusastraan. Jakarta: PT Gramedia 